\title{
Regeneration at the predilective damage sites of nerve trunks in treated leprosy
}

\author{
T. L. MIKO,$^{*} \dagger$ S. E. GSCHMEISSNER, \\ C. LE MAITRE, $\dagger$ Y. KINFU, $\S$ R. KAZEN $\dagger \&$ \\ J. H. PEREIRA
}

* Armauer Hansen Research Institute, Addis Ababa, Ethiopia; $\dagger$ All Africa Leprosy Rehabilitation and Training Centre, Addis Ababa, Ethiopia; $\ddagger$ EM Unit, Imperial Cancer Research Fund, Royal College of Surgeons of England, London, UK; §Department of Anatomy, Addis Ababa University, Addis Ababa, Ethiopia; and $\uparrow$ Department of Pathology, Royal College of Surgeons of England, London, UK

\section{Accepted for publication 30 April 1993}

\begin{abstract}
Summary Superficially located large and medium sized mixed peripheral limb nerves in active leprosy have previously been shown to have well-recognized fusiform swellings. It is generally agreed that these are the sites of predilective nerve involvement where the severest degeneration and fibrosis occur. A semiquantitative histopathological study on one of these sites, the flexor retinaculum region of the posterior tibial nerve, has been carried out on 14 treated leprosy patients who suffered from total sensory loss to the foot for between 2 and 40 years. The following observations were made: (1) large-scale nerve regeneration was present as characterized by numerous Schwann cells and unmyelinated axons which formed regeneration clusters; (2) thick myelinated axons were either absent or present only in very low numbers; (3) the intraneurial fibrosis was usually not severe; (4) the presence of active inflammation probably interfered with nerve regeneration; (5) it appeared that this regeneration started shortly after the onset of therapy and persisted for decades; (6) lepromatous cases were characterized by evenly distributed pathology, whereas borderline tuberculoid cases had an unevenly distributed pathology; (7) the massive nerve regeneration observed was functionally ineffective- - these findings indicate that the total nerve damage may affect the more peripheral nerve branches.
\end{abstract}

\section{Introduction}

Leprosy, with all its variety of skin manifestations, is essentially a peripheral nerve disease. Most previous studies on the histopathology of peripheral nerves in leprosy have

Correspondence: Dr T. L. Miko, Department of Pathology, University of Sheffield Medical School, P.O. Box 596, Sheffield S10 2UL. 
been confined to cutaneous nerve branches. Those studies on the histopathology of large mixed peripheral nerves in leprosy, all of them dealing with active cases, revealed either no ${ }^{1,2}$ or limited nerve regeneration. ${ }^{3-6}$ Dastur et al. ${ }^{4}$ demonstrated that the scanty nerve regeneration observed in active leprosy was blocked by fibrosis at the predilective damage sites of large mixed peripheral nerves of the limbs. These segments of predilective nerve involvement, manifesting themselves as fusiform swellings, are superficially located. ${ }^{7}$ Such segments are generally considered to be the sites of the most severe damage and hence fibrosis. ${ }^{4.8}$

To our knowledge, the present report is the first devised to study the site of predilective nerve involvement in treated leprosy cases suffering from loss of sensation. The primary goal of this study was to describe the distinctive histopathological patterns, with special attention to nerve regeneration, in the nerve trunks of advanced lepromatous (LL), borderline lepromatous (BL) and borderline tuberculoid (BT) leprosy cases that had received treatment.

\section{Material and methods}

We selected the lower third of the posterior tibial nerve for this study because it was more easily available than other nerve trunks, and in all 14 specimens were studied (Table 1). The nerves in cases 3, 4 and 8-14 were removed from patients undergoing muscle graft reconstruction, ${ }^{9}$ and in cases 1,2 and 5-7 we removed nerves from the amputated legs of leprosy patients immediately following surgery. All patients received anti-leprosy treatment. We collected 4 control samples (20-39 years) from the Department of Forensic Medicine, Menelik Hospital, Addis Ababa. In these cases, autopsy revealed no significant alterations except for the physical injury causing death. The control samples were collected within 8 hours of death.

From both the study and control cases, posterior tibial nerve samples were taken from under the upper half of the flexor retinaculum. All blocks were cut transversely. The following histological methods were employed. For general orientation and collagen: haematoxylin and eosin, and van Gieson. For myelin sheaths: Luxol fast blue staining on Helly fixed samples and $0 \cdot 5 \%$ osmium fixation followed by paraffin processing. For axons: modified Schoefield's silver impregnation on fresh-frozen cryostat sections fixed in $10 \%$ neutralized formaldehyde; and avidin-biotin immunoperoxidase method utilizing anti-neurofilament $200 \mathrm{kD}$ primary antibody (Boehringer, Mannheim, Germany) on ethanol-acetic acid-fixed paraffin sections. For Schwann cells: avidin-biotin immunoperoxidase method using anti-S-100 primary antibody (Dakopatts, Glostrup, Denmark) on buffered formaldehyde fixed paraffin sections, with no enzymatic digestion. Although the immunoperoxidase method for axons was more reproducible than the silver impregnation, the latter depicted the finest regenerating axons. For semiquantitative purposes, we found osmication and Luxol fast blue methods equally suitable. The parameters assessed are listed in Table 1.

\section{Results}

Although the lower third of the posterior tibial nerve was firm on palpation, no fusiform swelling was detected during surgery or macroscopical investigation of the dissected, amputated legs. 
Table 1. Histopathological findings on posterior tibial nerves and clinical characteristics of treated leprosy patients

.

Abbreviations: $\mathrm{T} x=$ Therapy; $\mathrm{LOS}=$ Loss of sensation; NA = information not available; $\mathrm{LEPR}=$ Lepromatous; TUB $=$ Tuberculoid

For semiquantitative evaluation, a grade system was used: - no; + slight/few; ++ moderate/several; +++ marked/many; ++++ above normal; \pm intermediate grades. Control nerves were the normal reference value $(+++)$ concerning the number of Schwann cells, axons and myelin sheaths. 'Uneven +++ ' means that the pathology was non-homogeneously distributed between and within individual fasciculi. 'Even +++ ' pathology means that the fascicular pathology was homogeneous.

Time since released from $\mathrm{Tx}$.

* Patients not released from Tx, although the WHO multidrug regime completed. In these cases duration of extra Tx was specified. All were receiving Tx at surgery.

** WHO multidrug Tx not completed. Attendance rate at surgery: 15/24 months.

*** Drugs taken irregularly. 

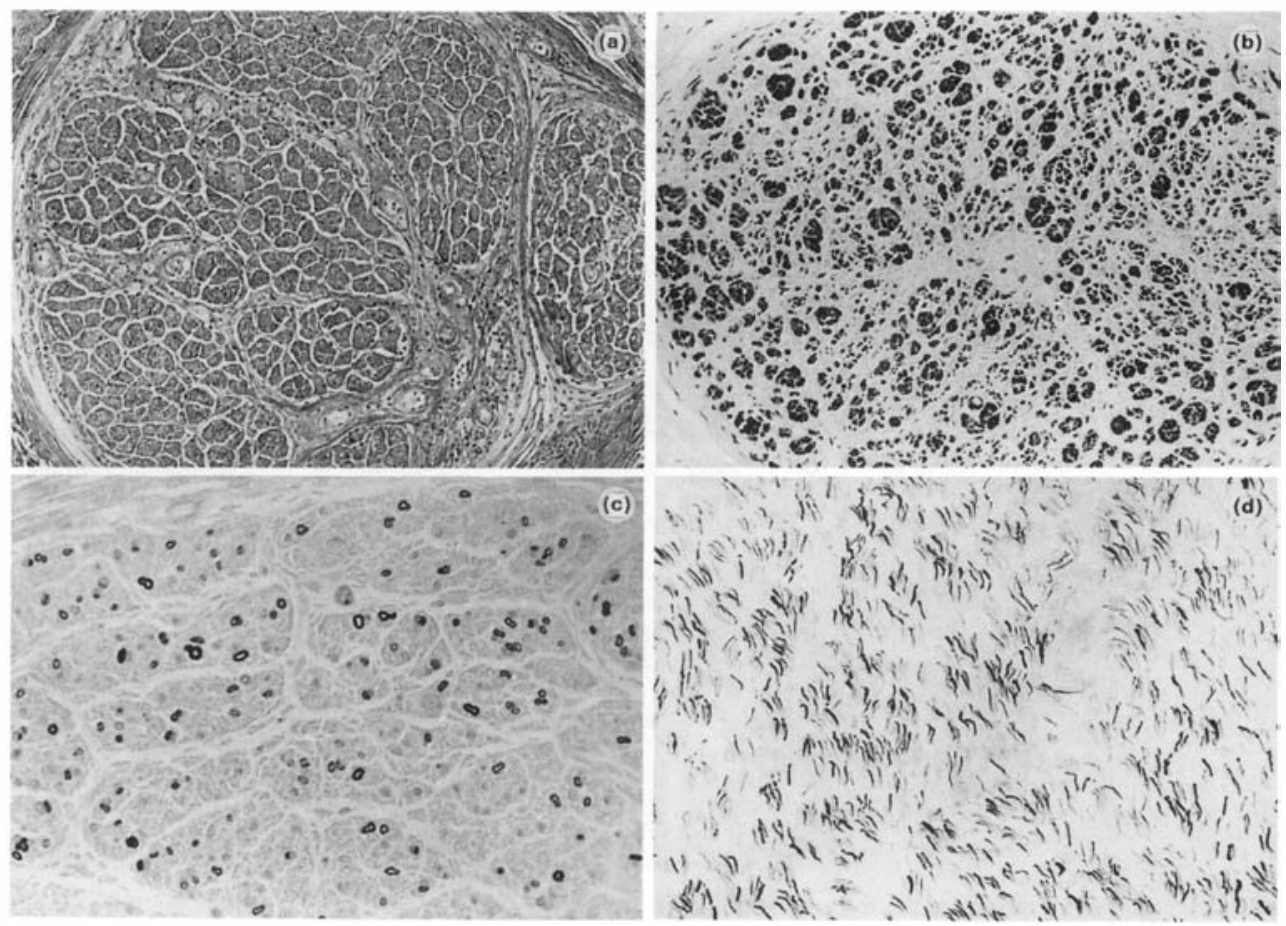

Figure 1. Histology of nerve trunks in lepromatous (LL) leprosy. a. The fascicle consists of evenly-distributed regeneration clusters of similar size. Van Gieson, $\times 115 \cdot 5$. b. The entire cross-sectional area of this fascicle reveals numerous Schwann cell processes, many arranged in discernible clusters. S-100, avidin-biotin complex, horseradish peroxidase method, $\times 115 \cdot 5$. c. The myelin pattern is characterized by a moderate number of evenly-distributed, small diameter sheaths. The contours of the Schwann cell clusters are discernible. Osmium fixation, paraffin embedding, $\times 462$. d. The axonal pattern is characterized by a high number of evenly distributed thin axons. Modified Schoefield's method, $\times 462$.

The major clinical and microscopical features are summarized in Table 1. The overall histological pattern of nerve trunks was homogeneous in LL cases (nos 1-5). All fasciculi appeared similar, and consisted of evenly distributed regeneration clusters (Figure 1). In contrast, the pattern in BT (cases 11-14) was not homogeneous. This pattern was characterized by increased and uneven fibrosis, and all pathological changes as well as nerve fibres of varying diameter were distributed in an uneven manner. In addition, focal changes were present within individual fasciculi (Figure 2). Lastly, in BL cases (nos 6-10) the pattern was intermediate with regard to fibrosis, inflammatory infiltrate and the diameter of nerve fibres.

Specifically, the degree of the residual inflammatory infiltrate was usually limited in cases $1-10,13$ and 14. In the case of slight lepromatous infiltrate, small numbers of foamy cells were present. Small epithelioid cell granulomas represented slight tuberculoid infiltrate, and in addition there was non-specific inflammation which consisted of mononuclear cells. In cases 11 and 12, large tuberculoid granulomas were present, surrounded by many lymphocytes (Figure $2 b$ ).

In LL and BL cases (nos 1-10) the Schwann cell number was high, usually above normal, coupled with similarly high numbers of unmyelinated axons. The Schwann cell processes formed groups which corresponded to regeneration units (Figure la, b). In the same cases, the number of myelinated axons was markedly decreased, so that there was a 


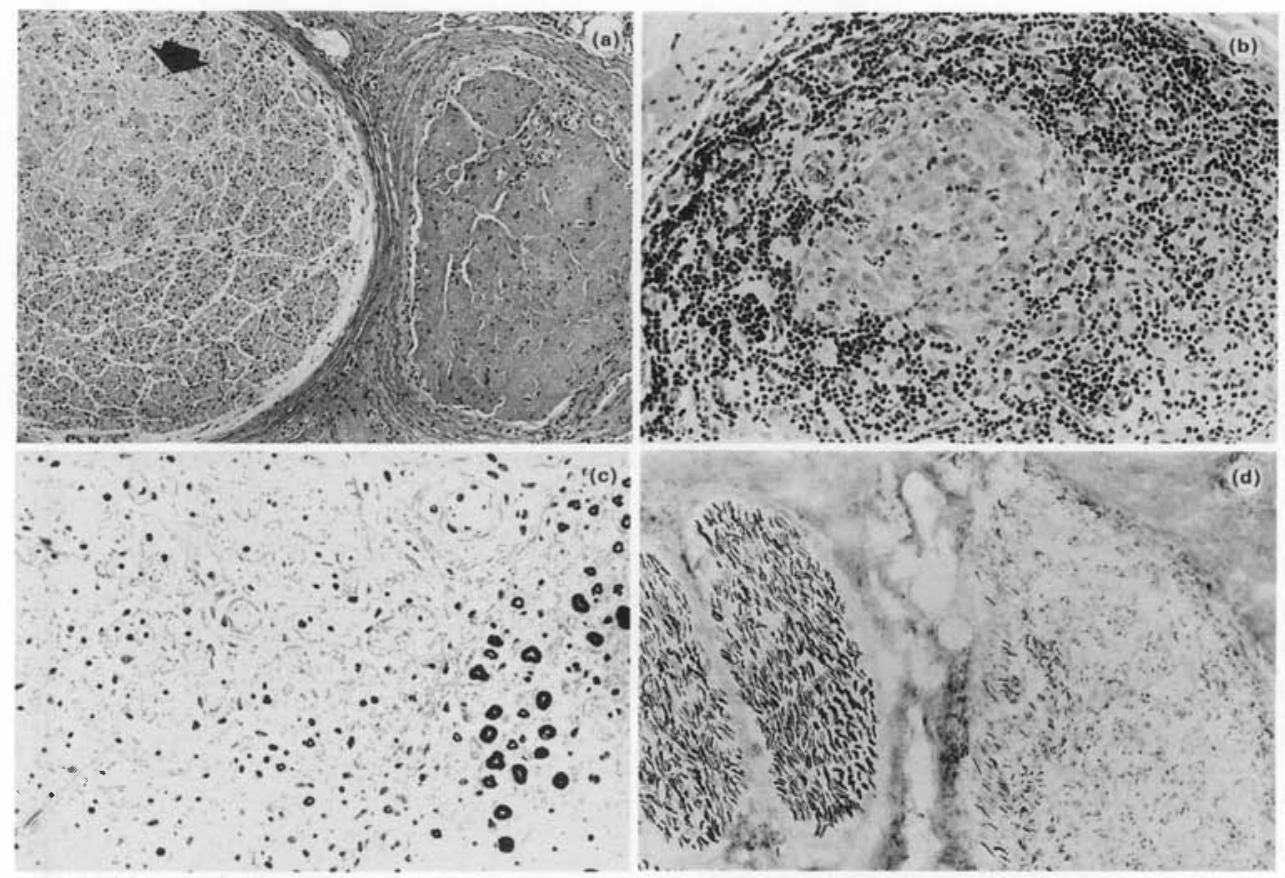

Figure 2. Histology of nerve trunks in borderline tuberculoid (BT) leprosy. a. The fascicle on the right shows advanced fibrosis. The fascicle on the left consists mostly of regeneration clusters; however, focal fibrosis is also present (arrow). $\mathrm{H} \& \mathrm{E}, \times 115 \cdot 5$. b. The neural tissue in this fascicle has been destroyed by a large tuberculoid granuloma surrounded by numerous mononuclear cells. H \& E, $\times 231$. c. This fascicle reveals marked loss of myelin sheaths. Note that the myelin sheaths show a much larger diameter range than those in lepromatous leprosy. Osmium fixation, paraffin embedding, $\times 462$. $d$. The marked inflammation in the right fascicle resulted in marked loss of axons. The left fascicle reveals numerous axons of varying thickness. Modified Schoefield's method, $\times 115 \cdot 5$.

strong shift towards small diameter axons. The myelin population was predominated by thin sheaths of small calibre which corresponded to newly-formed myelin surrounding regenerating axons (Figure $1 \mathrm{c}, \mathrm{d}$ ). In cases $1-10$, the numbers of both the unmyelinated and the newly-myelinated regenerating axons showed little variation, irrespective of the time elapsed since the onset of therapy. In the presence of tuberculoid infiltrates (cases 11 and 12), the number of Schwann cells was lower than in control cases and the lack of axons and myelin sheaths was conspicuous (Figure 2c, d). The most severe decrease of Schwann cells occurred together with marked fibrosis (case 14)-however, in this case the number of unmyelinated axons was not as low as in cases 11 and 12 which showed tuberculoid inflammation.

\section{Discussion}

Autopsy studies on peripheral nerves in active leprosy reveal the presence of spindleshaped thickenings at the sites of predilection in lepromatous cases, and more uniform thickenings in tuberculoid cases. ${ }^{1,2}$ The lack of the fusiform swelling in the ankle region of the posterior tibial nerve in our cases of advanced treated leprosy suggested that this swelling was characteristic of active leprosy. The swelling might have resulted from the 
inflammatory infiltrate and from the oedema present during the active phase of leprosy. The perineural fibrosis observed in our treated LL cases, probably for the same reason, was also less conspicuous than that usually reported in untreated leprosy. ${ }^{10}$

The pattern of numerous Schwann cell processes, moderate numbers of thin myelin sheaths and high numbers of thin regenerating axons observed in nerve trunks is typical of active but ineffective and persistent nerve regeneration. ${ }^{11-13}$ The few thick axons probably represent surviving fibres in numbers insufficient to provide any useful function. In LL and $\mathrm{BL}$ cases there appeared to be a complete lack of correlation between the degree of regeneration and the time elapsed since the start of therapy (see the extreme cases, 3 and 5). This fact suggested that the axonal regeneration may start shortly after the onset of therapy and may persist for decades. Large-scale nerve regeneration might also occur in BT leprosy, provided neither fibrosis nor inflammation were severe (case 13).

There seemed to be 2 exceptions to the above general pattern. First, a significant residual inflammatory infiltrate was present in $2 \mathrm{BT}$ patients who were still receiving treatment (cases 11 and 12). Case 12 had completed the WHO multidrug therapy only 6 months before surgery, whereas in case 11 the drugs had been taken irregularly. As in these cases the number of Schwann cells was still high, these cells either survived the most active phase of inflammation or they regenerated following this event. As axons were almost absent this would indicate that inflammation was hindering axonal regeneration; ${ }^{13-14}$ the absence of axons within the epithelioid granulomata also supported this theory. Secondly, case 14 was characterized by advanced fibrosis. This marked fibrosis seemed to result in a decreased number of Schwann cells. Despite the low number of Schwann cells, the number of regenerating axons was higher, in the absence of inflammation, than in cases 11 and 12, where inflammation was present. This also suggested that large-scale nerve regeneration may start only after a significant decrease of inflammation.

No histological change could be specifically related to previous leprosy reactions. It may be that the time elapsed since reactions obscured their effect. It is also possible that reactions had a more severe effect on peripheral branches.

Studies on the histopathology of nerves in leprosy usually concentrate on the inflammatory component (for review, see Ridley ${ }^{15}$ ), while a few deal with the neural tissue itself. In early leprosy, Shetty et al. ${ }^{16}$ described axonal atrophy in cutaneous branches which was attributed to permanent damage to the distal ends of these fibres. However, in active, untreated cases, degeneration with little or no regeneration was observed in the nerve trunks ${ }^{1.2,3,5,6}$ as well as in cutaneous branches. ${ }^{14}$ The active inflammation and the limited nerve regeneration recorded in these studies are in agreement with our findings. Furthermore, significant nerve regeneration was observed in a single case report, in which previous treatment could not be excluded as a cause. ${ }^{17}$ Finally, Dastur et al. ${ }^{4,18}$ described the presence of inflammatory infiltrate and acid-fast bacilli together with some nerve degeneration and regeneration. However, no information on therapy was included in these reports. The cases reported by Dastur et al ${ }^{4.18}$ showed the most severe nerve damage at the predilection sites and peripheral to this segment.

In addition to the striking regeneration, our cases also revealed that the overall histological pattern of the nerve trunks in treated LL and BT leprosy was conspicuously different. In LL cases this homogeneous pattern could be explained by the haematogenous spread of Mycobacterium leprae. ${ }^{19} \mathrm{We}$ observed that occasional small epithelioid granulomata may result from therapy (case 3); however, this did not affect the overall histological pattern. Histological upgrading did not occur in the LL group. In contrast, in 
BT cases the uneven distribution of the pathology was in agreement with the views on the fascicular spread of leprosy in this group. ${ }^{20}$ In BL cases, the histological pattern was intermediate as represented by cases 6 and 7. However, cases $8-10$ showed an increasingly more heterogeneous pattern, which could be explained as upgrading phenomena resulting from therapy.

In summary, the histology reported here was characteristic and of diagnostic value. The most important findings of the present study were the presence of large-scale, but functionally ineffective, regeneration in the ankle region of the posterior tibial nerve of treated leprosy patients, and the lack of complete fibrosis, at least at this level. The cause of this ineffective nerve regeneration is currently being studied in a detailed examination of more peripheral nerve segments, including the innervation of the skin.

\section{Acknowledgements}

This work was supported by grant No. 471/M from the British Leprosy Relief Association (LEPRA). AHRI is supported by the Norwegian and Swedish International Agencies for Development (NORAD and SIDA). Thanks are due to Dr Kimberley McGinnes for her constructive comments. The helpful contribution of Dr D. Dimitrov in providing access to normal nerves from his forensic autopsies is acknowledged.

\section{Note added in proofs}

The osmium-haematoxylin method for paraffin sections and the modified Schoefield's technique, mentioned in the Material and methods, have been published. Miko TL, Gschmeissner SE: Histological methods for assessing myelin sheaths and axons in human nerve trunks. Biotechnic Histochem (in press).

\section{References}

${ }^{1}$ Ermakova N. Studies on leprosy. I. The central, sympathetic and peripheral nervous systems. Int J Lepr, 1936; 4: 325-36.

Reddy DG, Krishnamurthy KR. Changes in peripheral nerves and spinal cord in leprosy. Ind J Med Res, 1962; 50: 692-7.

3 Job CK, Desikan KV. Pathologic changes and their distribution in peripheral nerves in lepromatous leprosy. Int J Lepr, 1968; 36: 257-70.

4 Dastur DK, Pandya SS, Antia NH. Nerves in the arm of leprosy: 2. Pathology, pathogenesis and clinical correlations. Int J Lepr, 1970; 38: 30-48.

5 Dayan AD, Sandbank U. Pathology of the peripheral nerves in leprosy: report of a case. J Neurol Neurosurg Psychiat, 1970: 33: 586-91.

6 Vieregge P, Reinhart V, Gerhard L, Schliwinski U, Jorg JR. Untreated borderline-leprosy in the ulnar nerve: light and electron microscopical studies. Lepr Rev, 1985; 56: 5-16.

7 Pfaltzgraff RE, Bryceson A. Clinical leprosy. In: Leprosy, Hastings RC, (ed.), Edinburgh: Churchill Livingstone, 1985.

${ }^{8}$ Dastur DK. Pathology and pathogenesis of predilective sites of nerve damage in leprous neuritis. Neurosurg Rev, 1983; 6: 139-52.

9 Pereira JH, Palande DD, Subramanian A, Narayanakumar TS, Curtis J, Turk JL. Denaturated autologous muscle graft in leprosy. Lancet, 1991; 338: 1239-40.

${ }_{10}$ Pearson JMH, Weddell AGM. Perineural changes in untreated leprosy. Le pr Rev, 1975; 46: 51-67.

1 Sanders FK, Young JZ. The influence of peripheral connections on the diameter of regenerating nerve fibres. J Exp Biol, 1946; 22: 203-12.

12 Mackinnon SE, Hudson AR, Trued S, Hunter DA. Nerve regeneration in the rat model. Periph Nerve Repair Regeneration, 1986; 1:41-8.

13 Mackinnon SE, Dellon AL. Surgery of the peripheral nerve. New York-Stuttgart, Thieme: 1988. 
14 Tzourio C, Said G, Millan J. Asymptomatic nerve hypertrophy in lepromatous leprosy: a clinical, electrophysiological and morphological study. J Neurol, 1992; 239: 367-74.

15 Ridley DS. Pathogenesis of leprosy and related diseases. London: Wright Butterworth, 1988.

16 Shetty VP, Antia NH, Jacobs JM. The pathology of early leprous neuropathy. J Neurol Sci, 1988; 88: 115-31.

17 Gibbels E, Henke U, Klingmuller G, Haupt WF. Myelinated and un myelinated fibresi n sural nerve biopsy of a case with lepromatous leprosy - a qualitative approach. Int J Lepr, 1987; 55: 333-7.

18 Dastur DK, Razzak ZA. Degeneration and regeneration in teased nerve fibres. Acta Neuropath, 1971; 18: 286-98.

19 Skinsnes OK. M. leprae and its 'affinity' for nerves. Int J Lepr, 1974; 39: 762-5.

${ }^{20}$ Sunderland S. The internal anatomy of nerve trunks in relation to the neural lesions of leprosy. Brain, 1973; 96: $865-88$.

Lepr Rev (1993) 64, 330-337

\title{
Régénération aux sites lésionnels de prédilection des troncs nerveux dans la lepre traitée
}

\author{
T. L. Miko, S. E. Gschmeissner, C. Le Maitre, Y. Kinfu, R. Kazen et \\ J. H. PEREIRA
}

Résumé Il a déjà été démontré que des nerfs périphériques mixtes des membres, de tailles moyene et grande situés en surface, présentent des enflures fusiformes bien reconnues. Il est généralement convenu que ce sont les sites de prédilection des complications nerveuses, c'est-à-dire les sites de dégénérescence et de fibrose les plus graves. Nous avons fait une étude histopathologique semi-quantitative de l'un de ces sites, la région du ligament du fléchisseur du nerf tibial postérieur, chez 14 sujets lépreux traités qui présentaient une perte sensorielle totale du pied depuis 2 à 40 ans. Nous avons fait les observations suivantes: (1) présence d'une régénération nerveuse à grande échelle qui se caractérisait par de nombreuses cellules de Schwann et des axones amyéliniques qui formaient des noyaux de régéneration; (2) les axones myélinques épais étaient soit absents soit en très faibles nombres; (3) la fibrose intraneurale n'était généralement pas grave; (4) la preśence d'inflammation active gênait probablement la régénération nerveuse; (5) cette régénération semble avoir commencé peu de temps après le début du traitement et s'est poursuivie pendant des dizaines d’années; (6) les cas lépromateux se caractérisaient par une pathologie uniformément distribuée tandis que dans les cas tuberculoïdes indéterminés, la pathologie était irrégulièrement distribuée; (7) la régénération nerveuse massive était san efficacité fonctionnelle. Ces résultats indiquent que les lésions nerveuses totales affectent peut-être plus les ramifications nerveuses les plus périphériques.

\section{Regeneración de las áreas predilectas de daño en los troncos nerviosos en la lepra tratada}

\author{
T. L. Miko, S. E. Gschmeissner, C. Le Maitre, Y Kinfu, R. Kanzen y \\ J. H. Pereira
}

Resumen Ya se observó quelos nervios periféricos mix tos de tamaño grande y mediano y ubicación superficial en las extremidades cuentan con tumefacciones fusiformes. En general se acepta que éstas son áreas predilectas de participación nerviosa en las que so produce la degeneración y fibrosis más severa. Se llevó a cabo un estudio histopatológico semicuantitativo de una de estas áreas, la región del rentináculo del flexor del nervio tibial posterior, en 14 pacientes de lepra tratados, con total pérdida de sensación en el pie durante un período de 4 a 40 años. Se realizaron las siguientes observaciones: (1) presencia de regeneración nerviosa a gran escala, caracterizada por las numerosas células de Schwann y axones no mielinizados que formaban los grupos de regeneración, (2) axones gruesos mielinizados ausentes o presentes en bajo número, (3) la fibrosis intraneural generalmente no es severa, (4) la presencia de inflamación activa probablemente interfirió con la regeneración nerviosa, (5) parece que tal regeneración se inició poco tiempo después de comenzada la terapia y perduró durante décadas, (6) los casos lepromatosos se caracterizaron por una patología de distribución no uniforme, (7) la masiva regeneración nerviosa observada era ineficaz desde el punto de vista funcional. Estos hallazgos indican que el daño nervioso total puede afectar las ramas nerviosas más periféricas. 